\title{
Two Cases of $\mathrm{H}_{2}$-Receptor Antagonist Hypersensitivity and Cross- Reactivity
}

\author{
Woo-Jung Song, ${ }_{1}^{1,2}$ Min-Hye Kim, ${ }_{1}^{1,2}$ Sang-Min Lee ${ }_{1}^{3}$ Yong-Eun Kwon, ${ }_{1}^{4}$ Sae-Hoon Kim, ${ }_{1}^{1,2,5}$ Sang-Heon Cho, ${ }_{1}^{1,2}$ \\ Kyung-Up Min, ${ }^{1,2}$ You-Young Kim, ${ }^{1,2}$ Yoon-Seok Chang ${ }^{1,25 *}$ \\ ${ }^{1}$ Department of Internal Medicine, Seoul National University College of Medicine, Seoul, Korea \\ ${ }^{2}$ Institute of Allergy and Clinical Immunology, Seoul National University Medical Research Center, Seoul, Korea \\ ${ }^{3}$ Department of Internal Medicine, Armed Forces Capital Hospital, Seongnam, Korea \\ ${ }^{4}$ Department of Internal Medicine, Chosun University College of Medicine, Gwangju, Korea \\ ${ }^{5}$ Department of Internal Medicine, Seoul National University Bundang Hospital, Seongnam, Korea
}

This is an Open Access article distributed under the terms of the Creative Commons Attribution Non-Commercial License (http://creativecommons.org/licenses/by-nc/3.0/) which permits unrestricted non-commercial use, distribution, and reproduction in any medium, provided the original work is properly cited.

$\mathrm{H}_{2}$-receptor antagonists, such as cimetidine, ranitidine and famotidine, are some of the most commonly prescribed medications for gastric acid-related disorders. These compounds are generally well-tolerated and anaphylactic reactions to them are rare. Here, we report two cases of $\mathrm{H}_{2}$-receptor antagonist-induced anaphylactic reactions: the first presented with sudden dyspnea, sneezing, urticaria, and swelling of the eyelids after ranitidine intake. The second presented with sudden severe urticaria, facial swelling, chest discomfort, dizziness, and hypotension. Possible cross-reactivity with other $\mathrm{H}_{2}$-receptor antagonists was assessed by oral challenge and skin tests. To date, only a few reports addressing cross-reactivity among $\mathrm{H}_{2}$-receptor antagonists have been published. We review the literature and summarize the data available on drug cross-reactivity in $\mathrm{H}_{2}$-receptor antagonist hypersensitivity.

Key Words: Histamine $\mathrm{H}_{2}$ receptor antagonists; cross reactions; drug hypersensitivity; allergy

\section{INTRODUCTION}

$\mathrm{H}_{2}$-receptor antagonists inhibit histamine action on gastric parietal cells, thus decreasing acid production. Such therapy is usually indicated for the treatment of peptic ulcers and gastro-esophageal reflux disease. These agents are typically well-tolerated, and severe hypersensitivity reactions are extremely rare. ${ }^{1}$ Here, we report two cases of severe hypersensitivity reactions induced by $\mathrm{H}_{2}$-receptor antagonists and possible cross-reactivities between drugs of this class.

\section{CASE REPORT}

\section{Case 1}

A 42-year-old female visited our clinic having recently suffered two episodes of angioedema. About 1 month earlier, she developed dyspnea, sneezing, and swelling of the eyelids $30 \mathrm{~min}$ after taking a single $150 \mathrm{mg}$ ranitidine tablet $\left(\right.$ Zantac $^{\circledR}$, GlaxoSmithKline, Brentford, UK). One week later she again took ranitidine $\left(\right.$ Zantac $^{\circledR}$ ) for dyspepsia, and once more developed the allergic

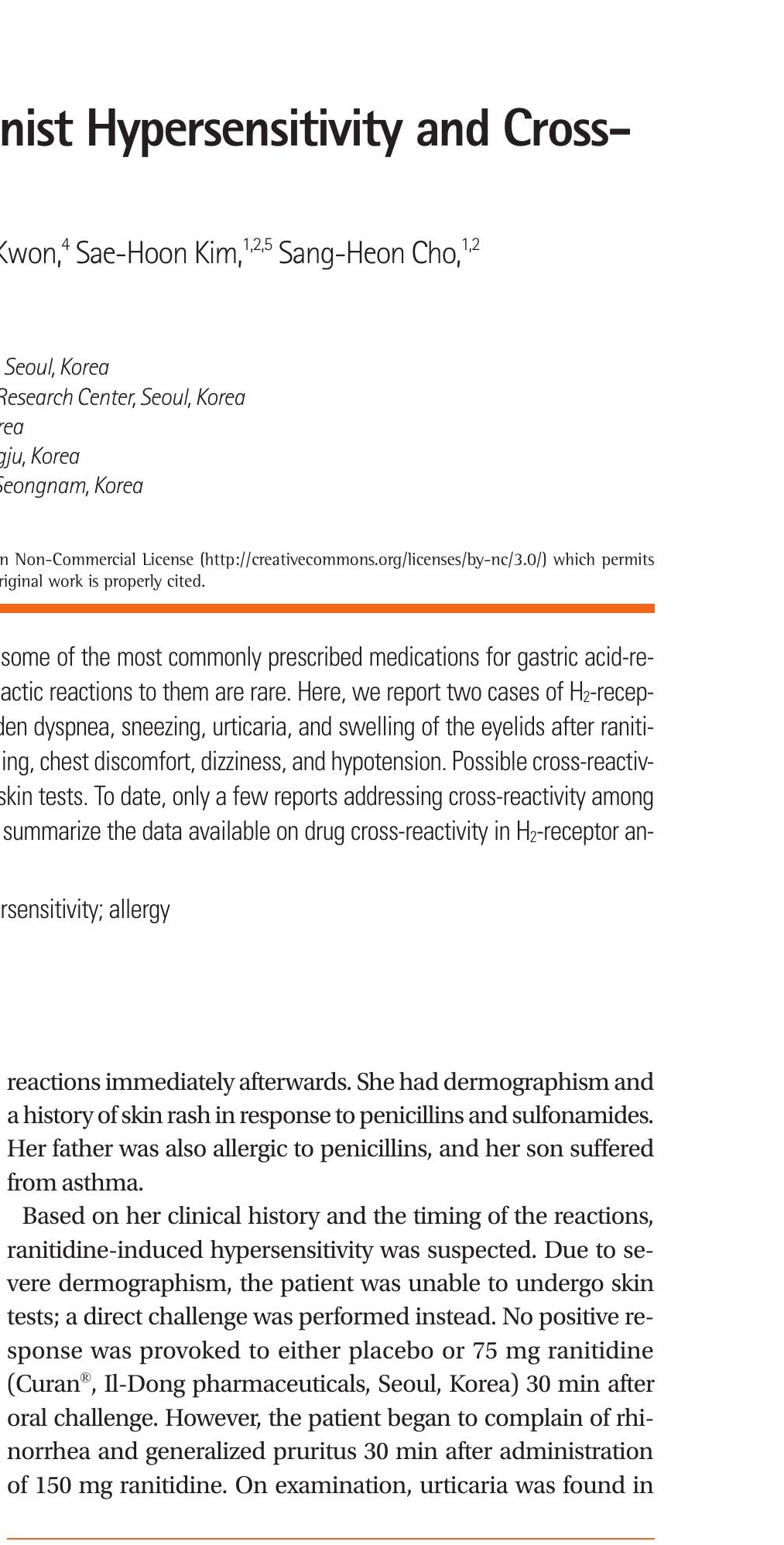

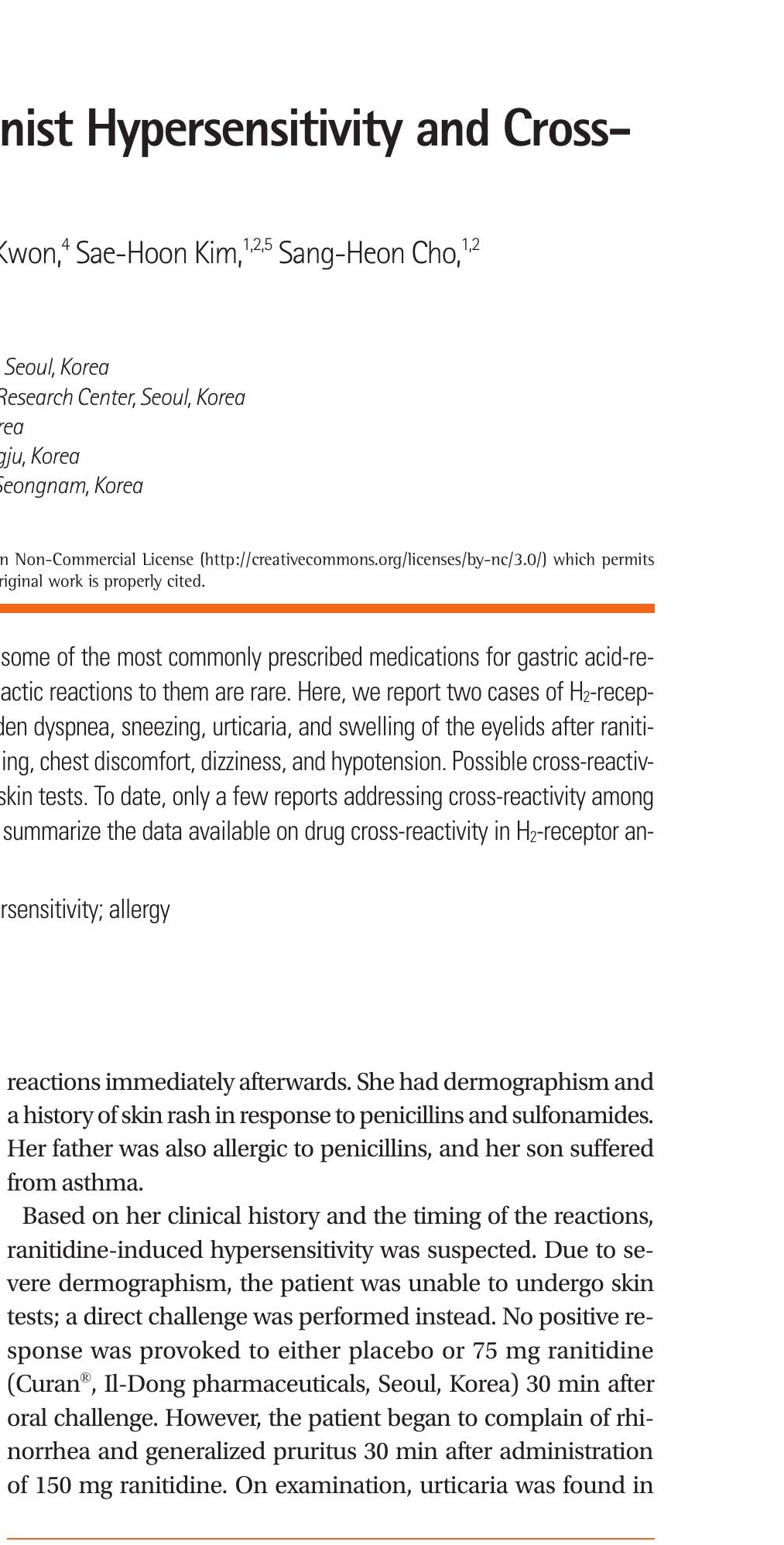

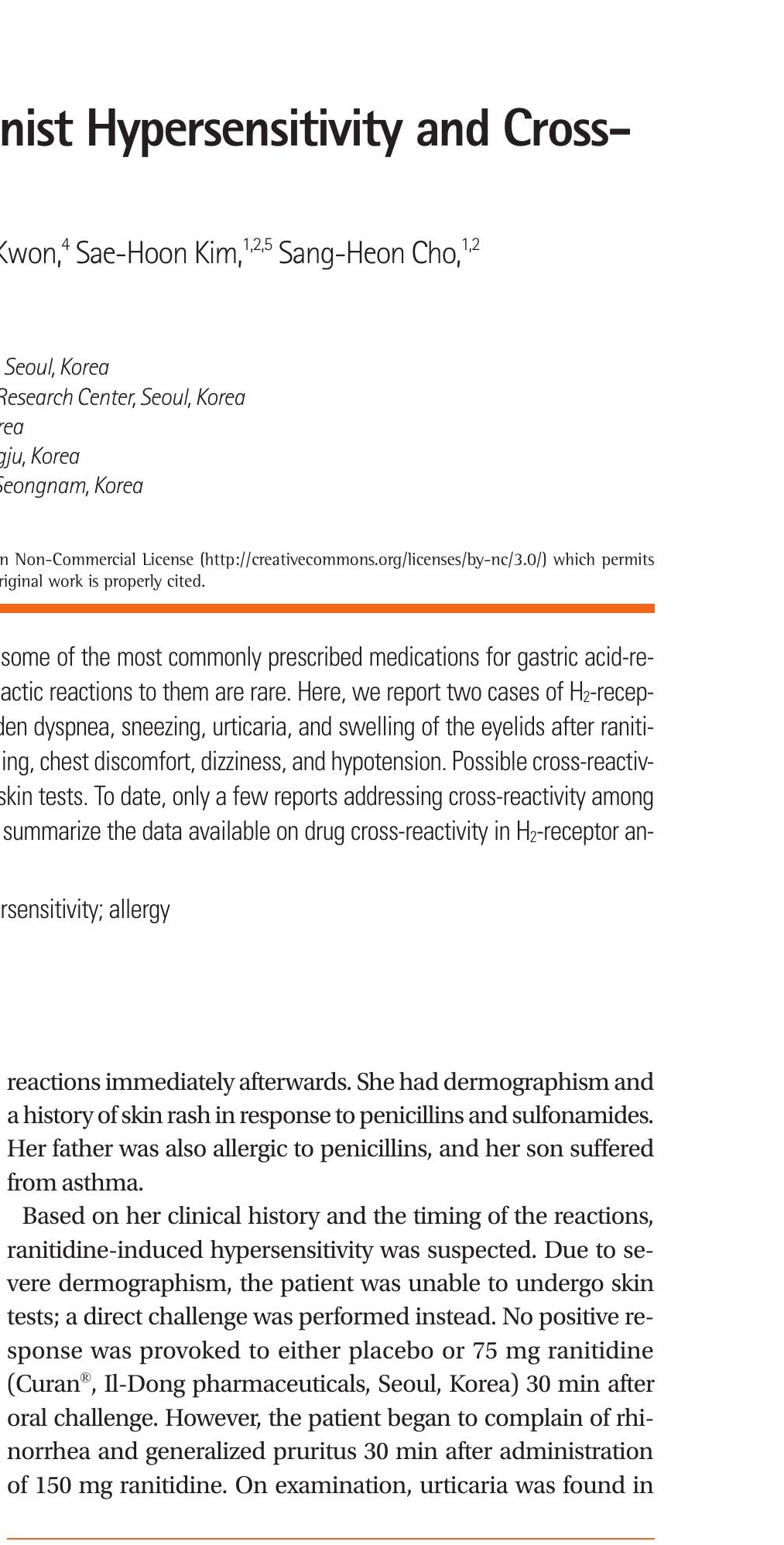

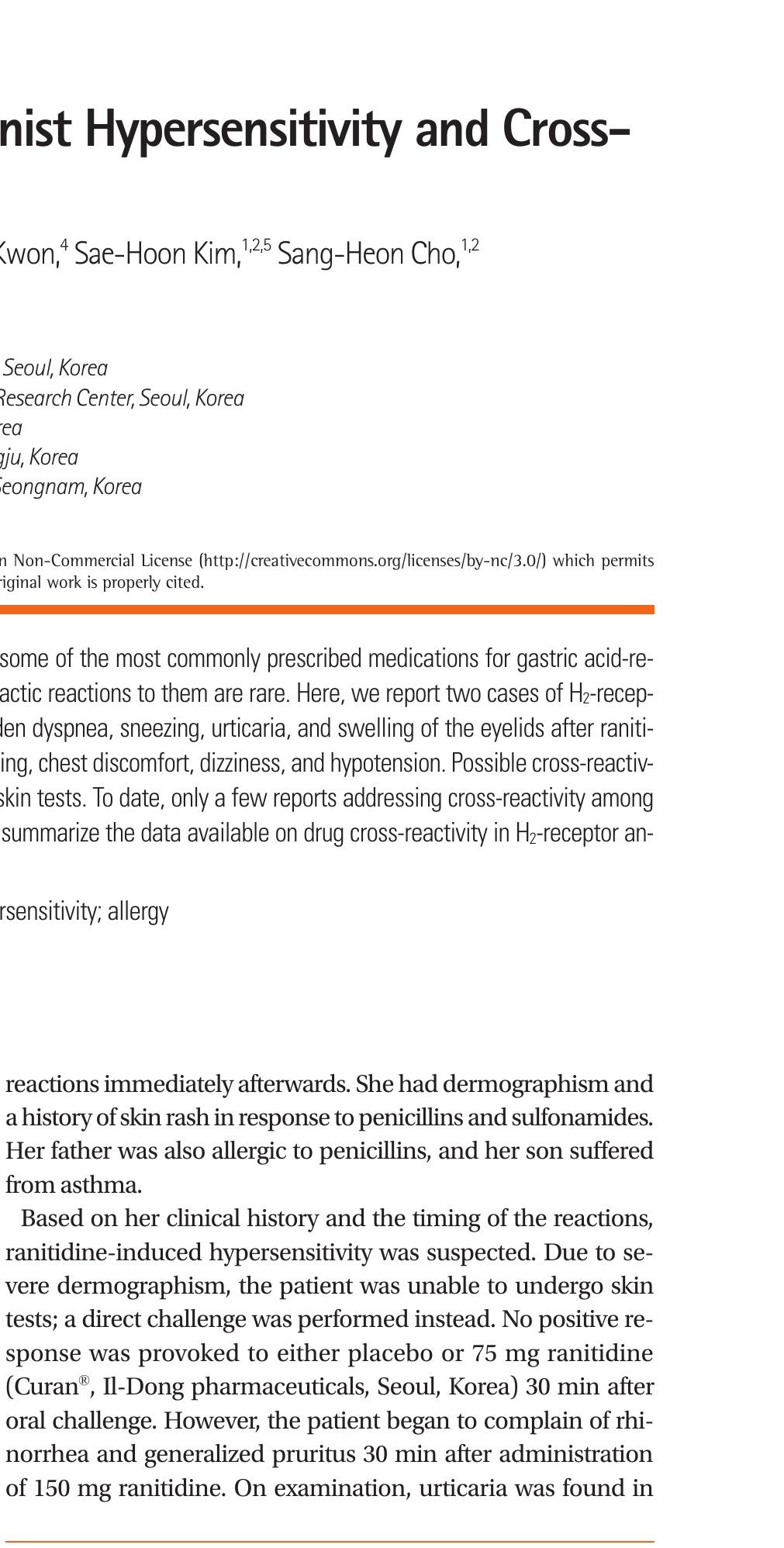

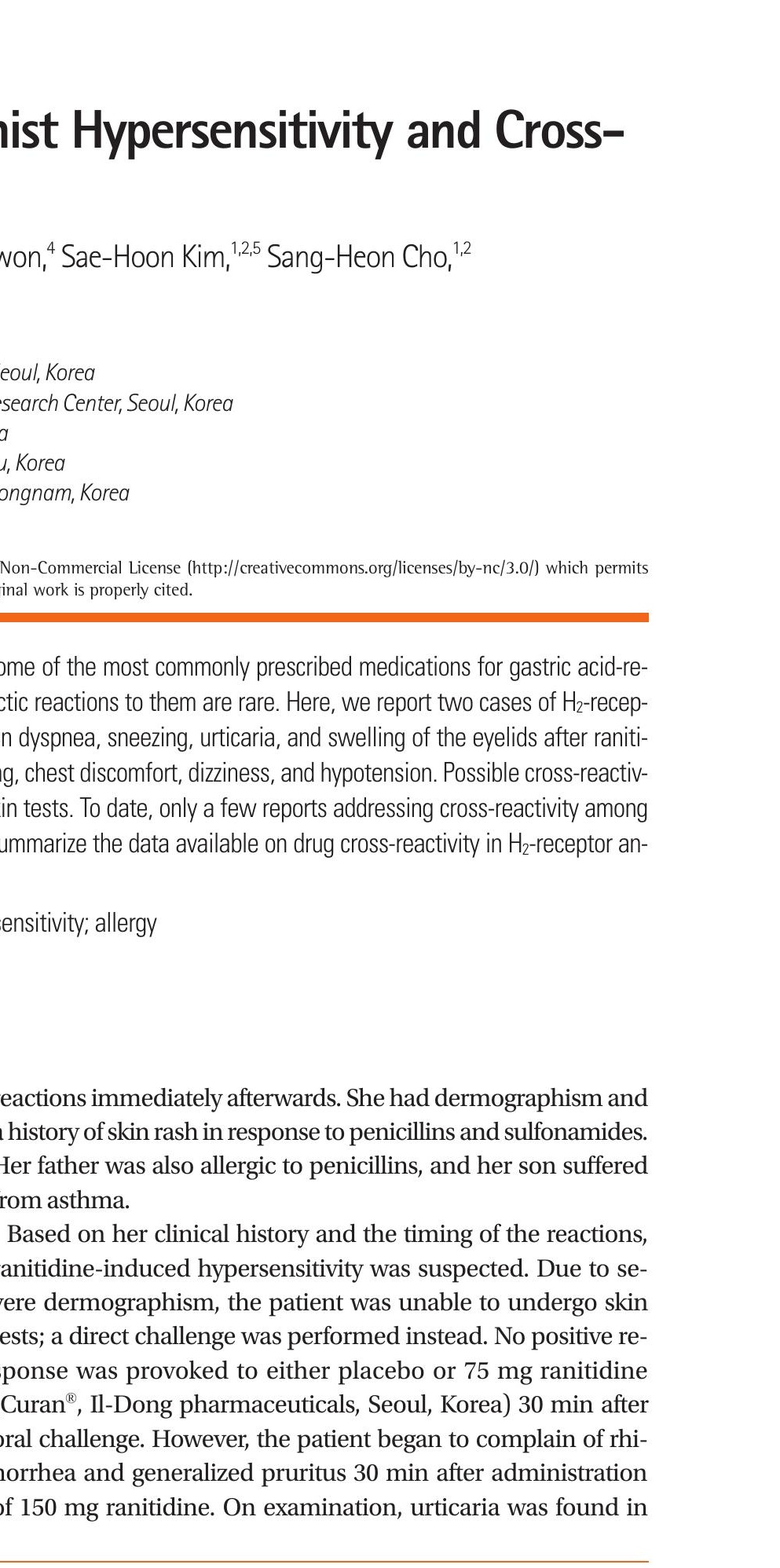

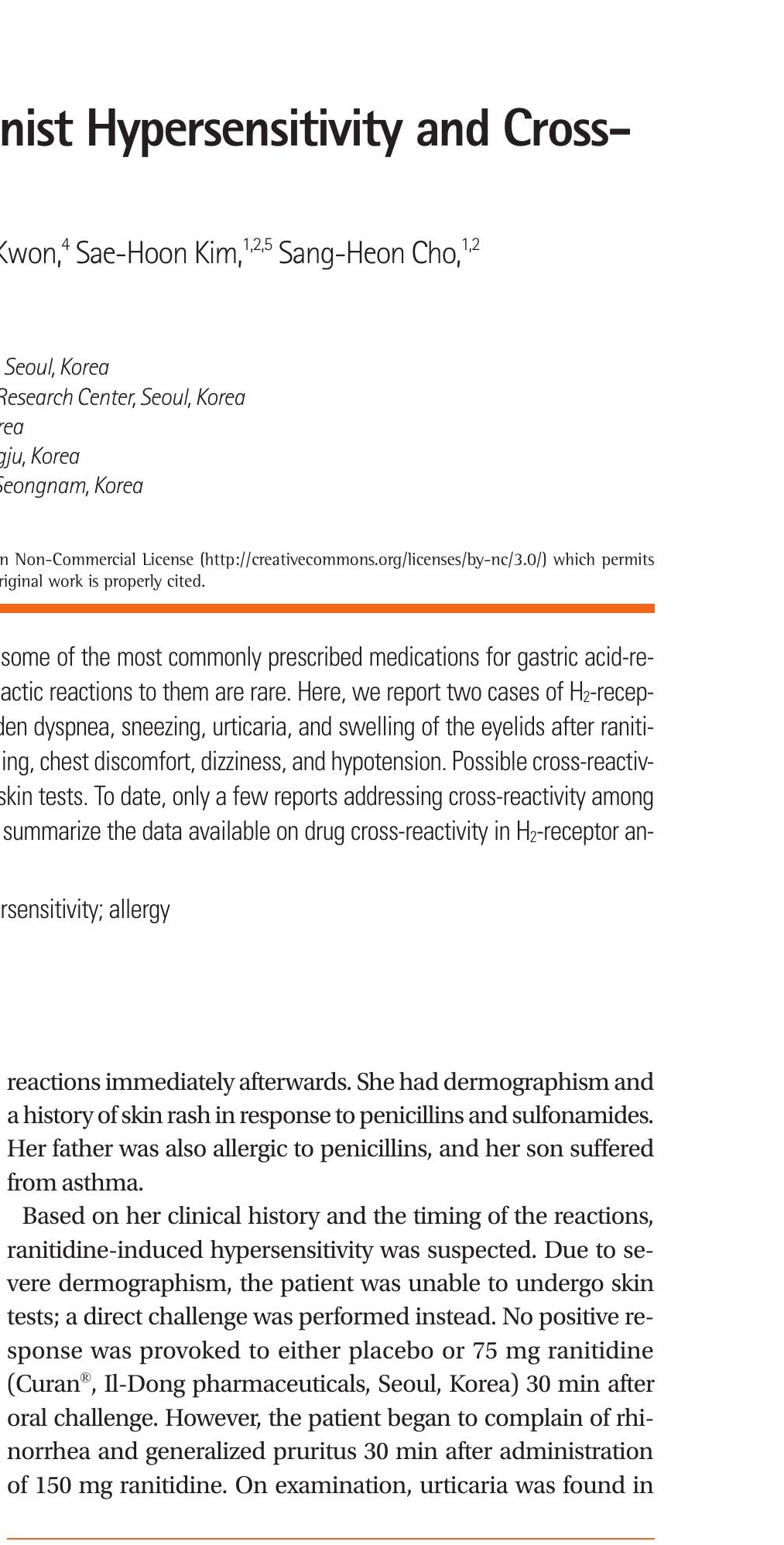

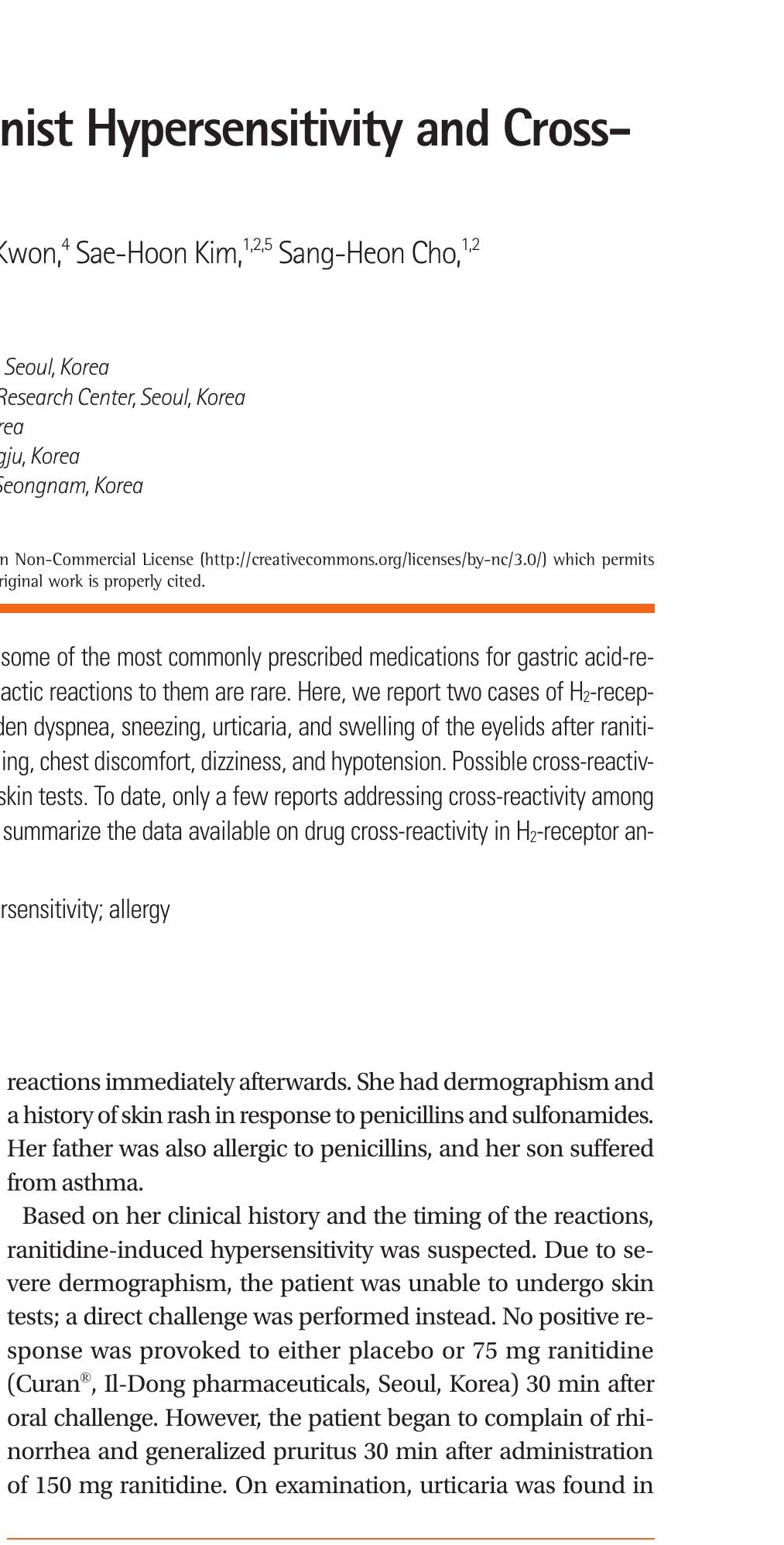

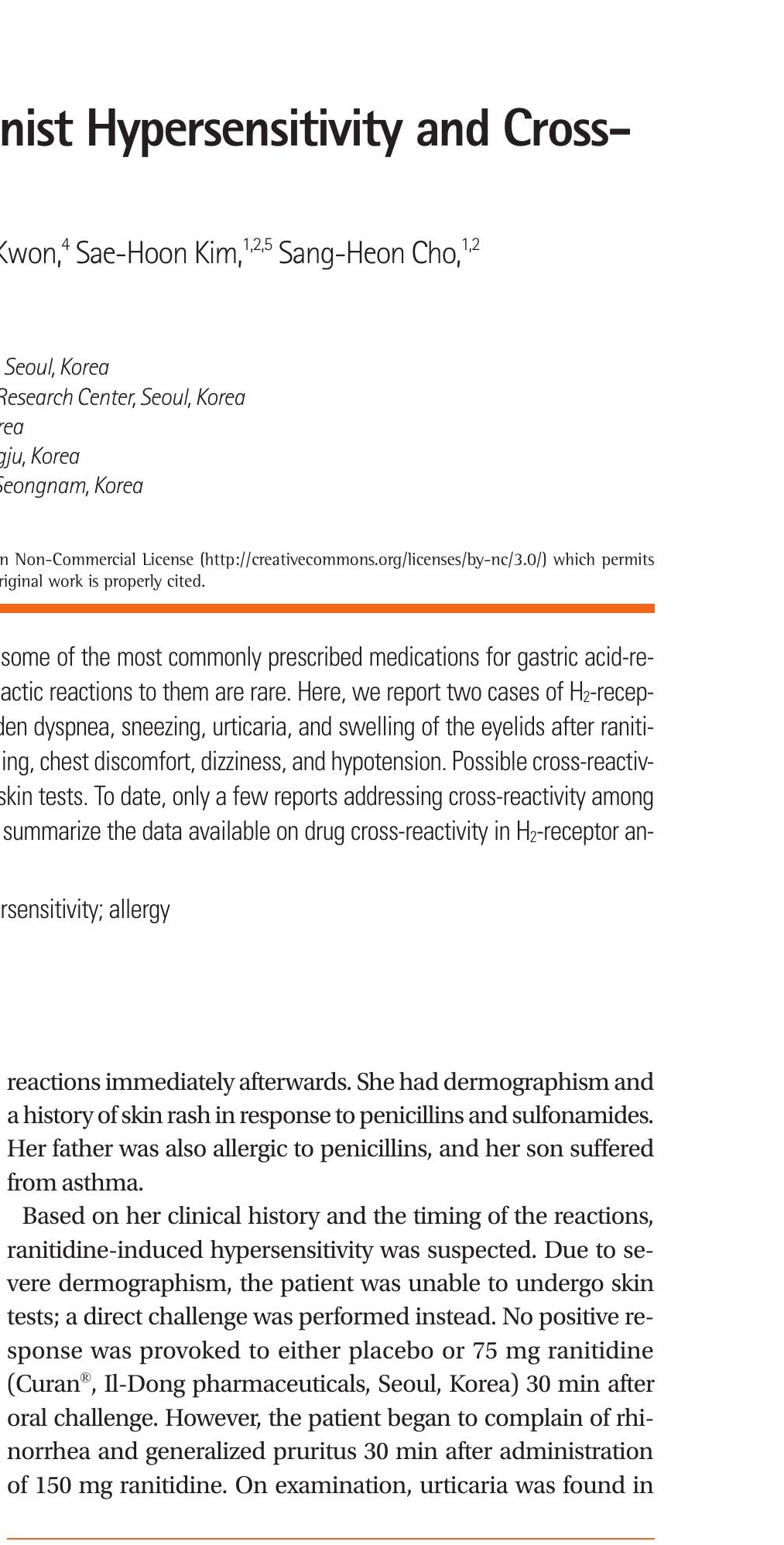

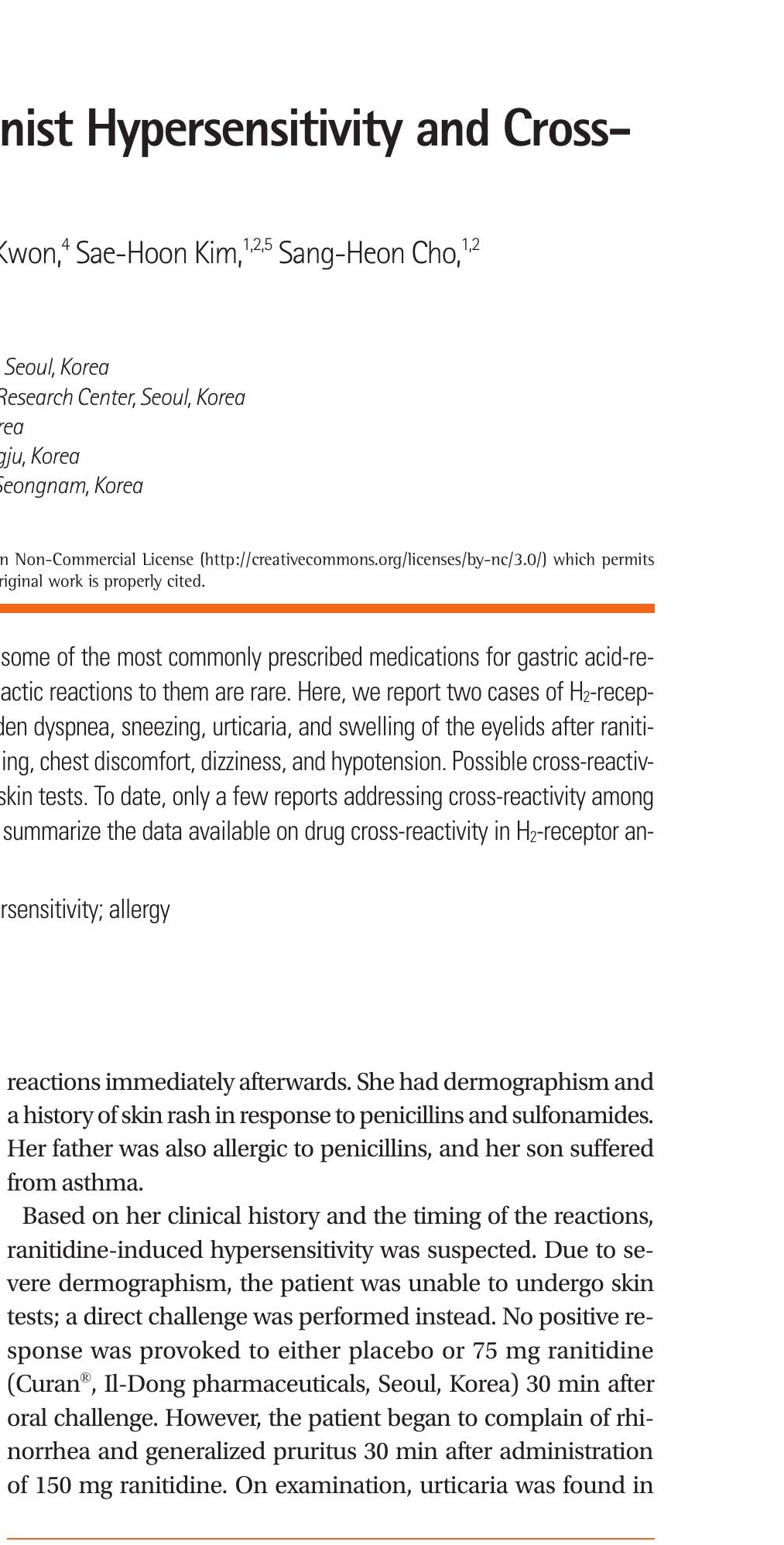

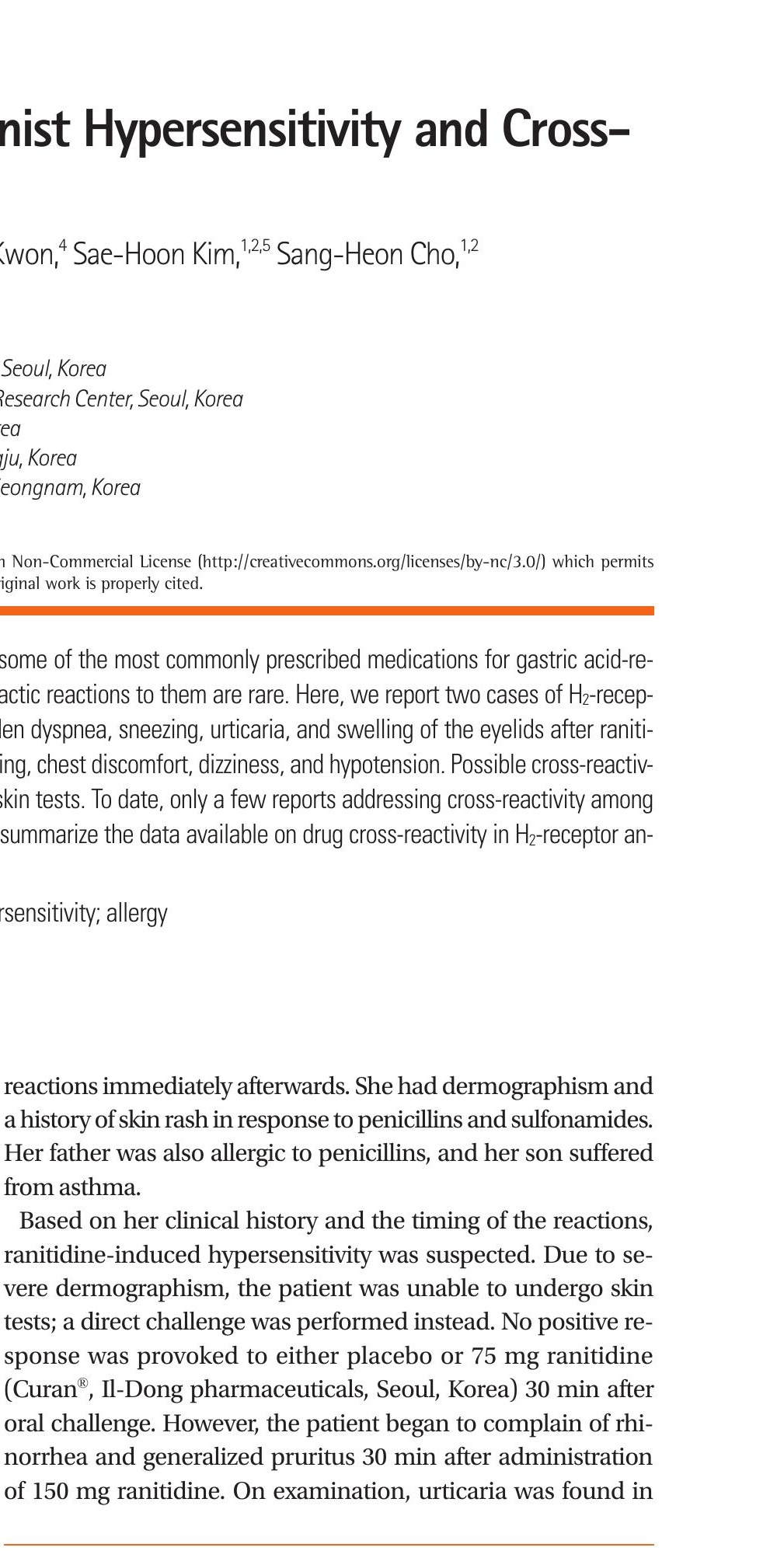

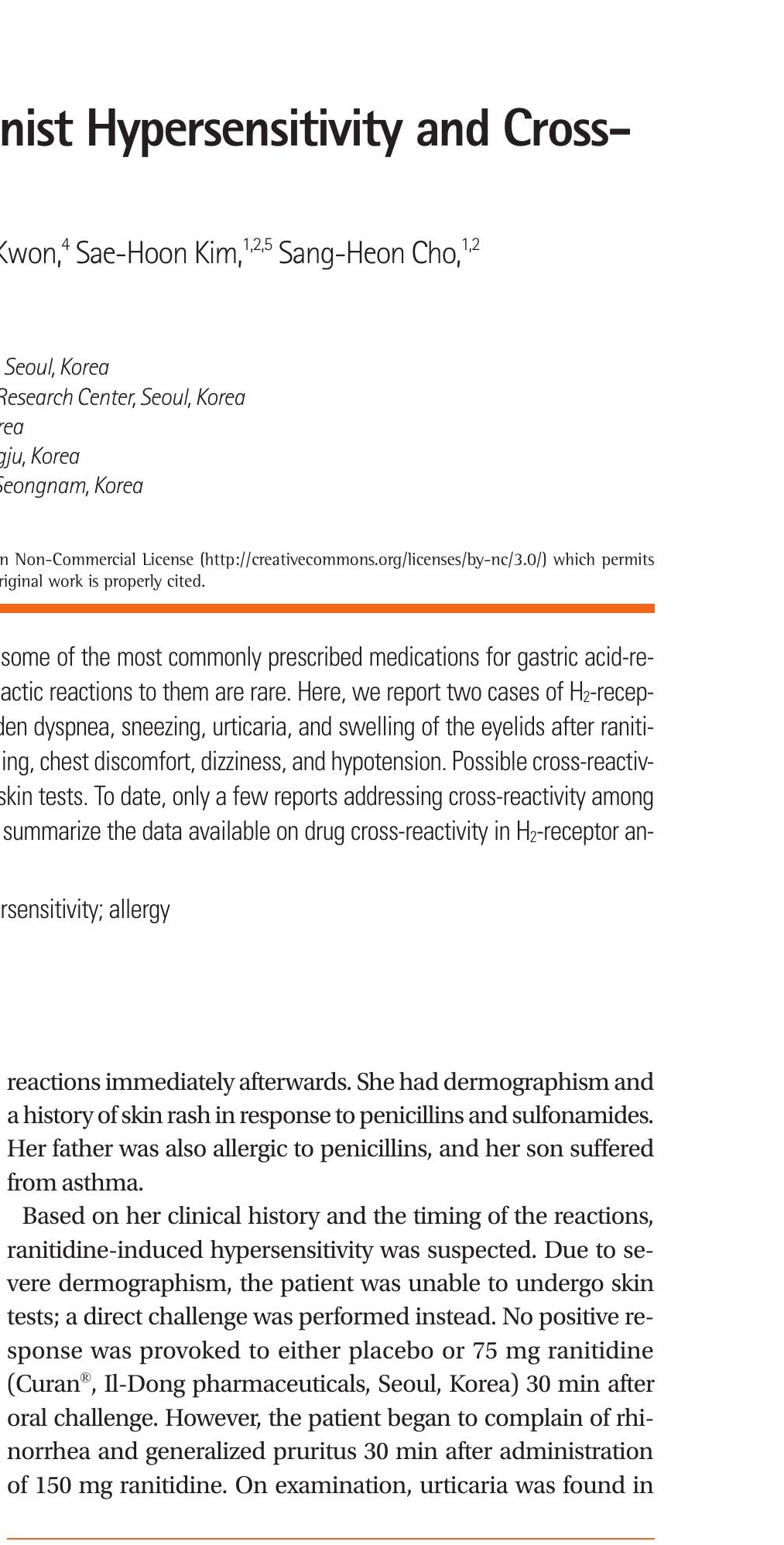

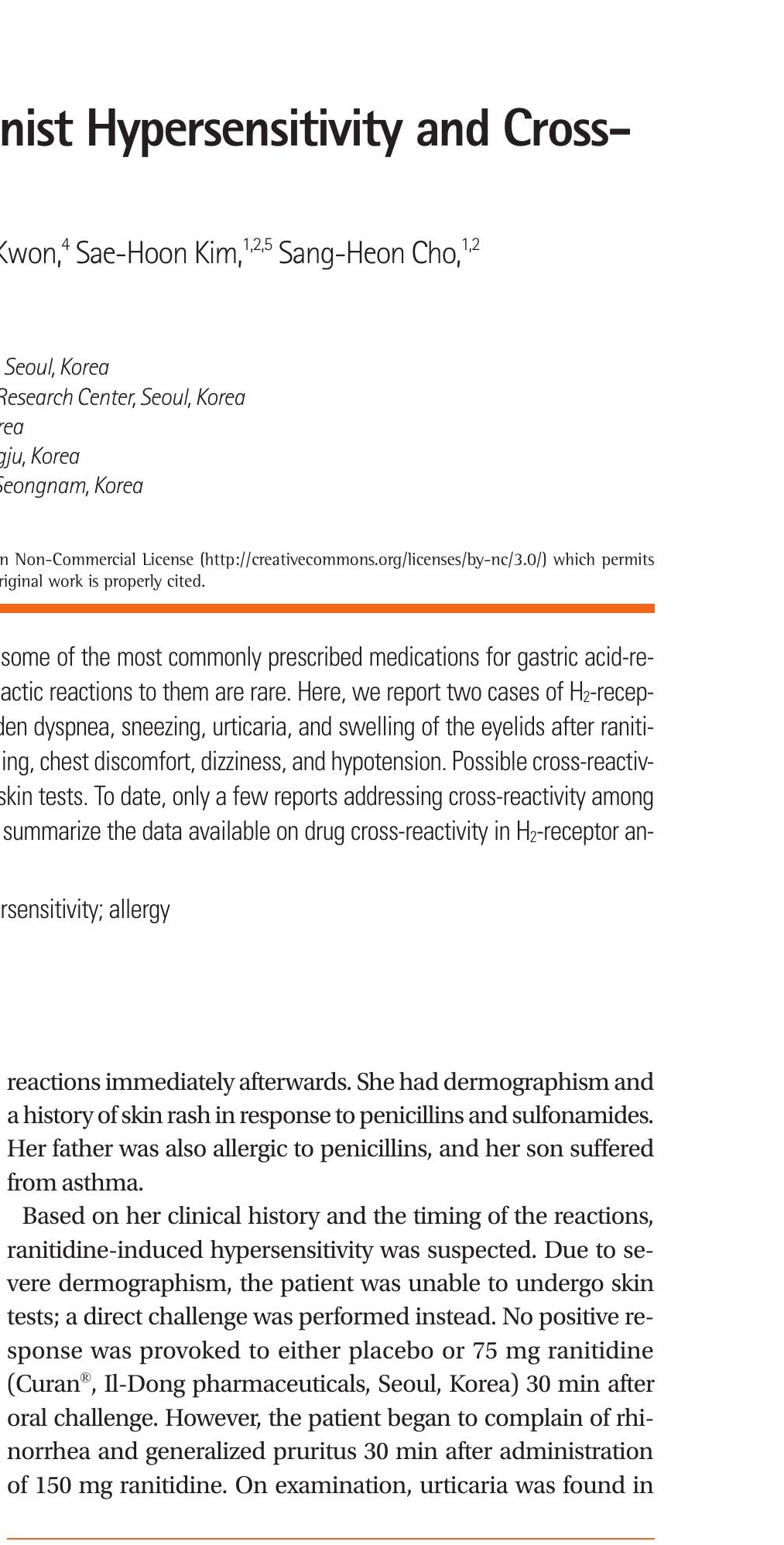

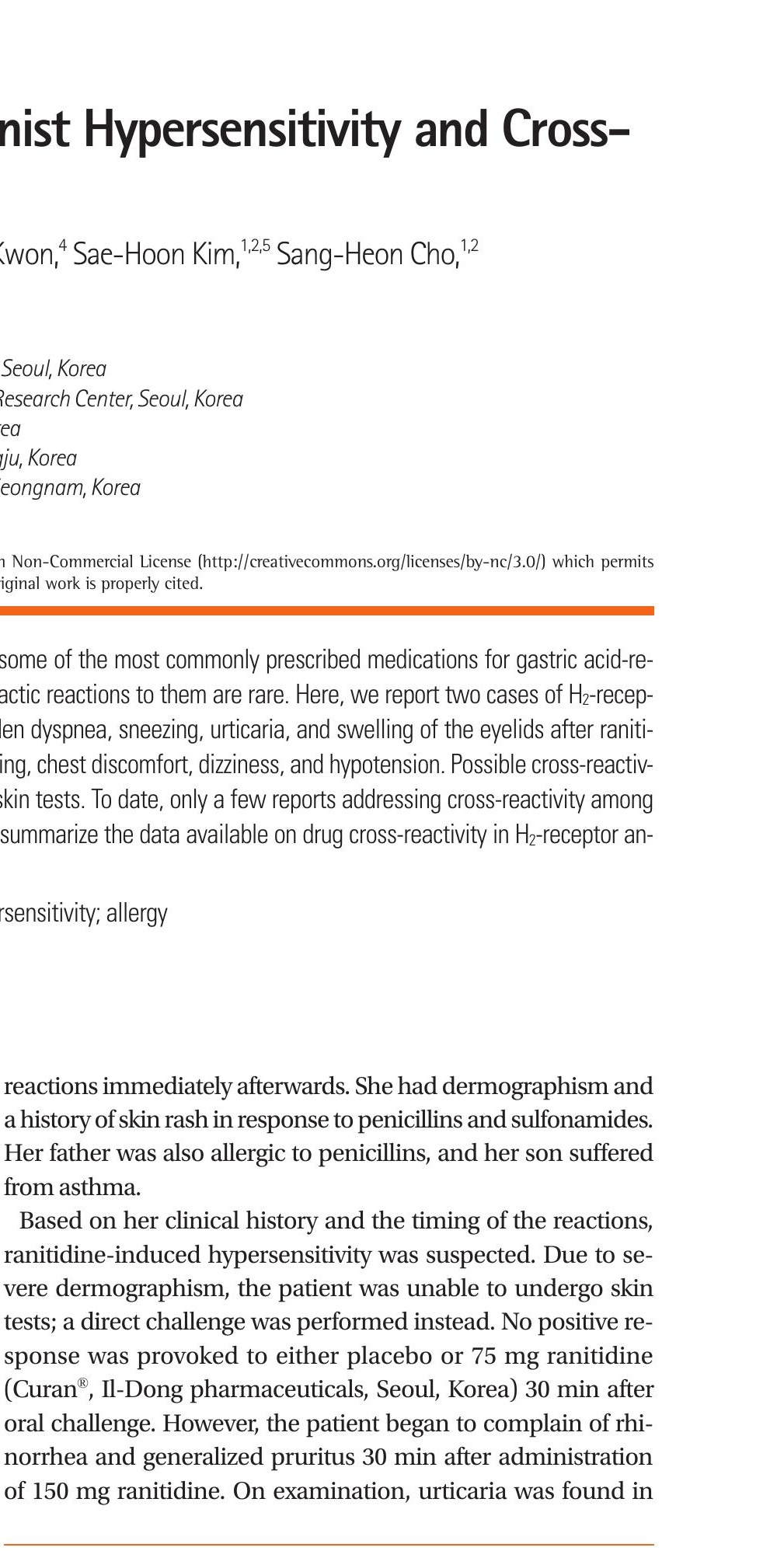

Correspondence to: Yoon-Seok Chang, MD, PhD, Department of Internal Medicine, Seoul National University Bundang Hospital, 300 Gumi-dong, Bundang-gu, Seongnam 463-802, Korea.

Tel: +82-31-787-7023; Fax: +82-31-787-4052; E-mail: addchang@snu.ac.kr Received: June 4, 2010; Accepted: August 10, 2010

- There are no financial or other issues that might lead to conflict of interest. 
the axilla and ears. No significant change in FEV1 or blood pressure was observed. The test was stopped and the symptoms treated with methylprednisolone and chlorpheniramine.

One month later, another challenge was performed with famotidine (Gaster ${ }^{\mathbb{B}}$, Astellas Pharma Inc., Tokyo, Japan). Thirty minutes after challenge with $10 \mathrm{mg}$, the patient reported itching and a hot sensation in the palms. Because we decided that these symptoms were non-specific, we proceeded with a challenge using $20 \mathrm{mg}$ famotidine. Ten minutes after ingesting, she began to complain of not only itching of the palms, but also sudden sneezing and rhinorrhea. The test was immediately stopped, and symptoms subsided spontaneously without progression. As a result, we concluded that this patient was allergic to ranitidine and famotidine. Thus, we diagnosed this case as ranitidineinduced hypersensitivity reaction with possible cross-reactivity to famotidine.

\section{Case 2}

An 80-year-old male was transferred to the emergency room due to chest discomfort and dizziness. On arrival, his blood pressure was $60 / 40 \mathrm{mmHg}$ and he was wheezing. He looked confused, and had a swollen face and severe generalized urticaria. He recovered after immediate administration of epinephrine, systemic corticosteroids, and chlorpheniramine. He was found to have taken chlorpheniramine, acetaminophen, and cimetidine $10 \mathrm{~min}$ before the onset of his symptoms because of mild urticaria, which allegedly developed after pork intake. Immediately after taking these medications, he developed severe generalized urticaria, facial swelling, chest discomfort, dyspnea, and dizziness.

He suffered from asthma and angina pectoris, and was taking inhaled budesonide/formoterol, nitrate, carvedilol, nicorandil and triflusal. He had no other medical history, known adverse drug reactions, or relevant family history. Initial tests, including cardiac enzymes and an electrocardiogram, revealed no remarkable abnormalities. Two weeks after recovery, a skin prick test was performed for common inhalant and food allergens, including pork. These revealed weak skin positivity to only willow, timothy and meadow, but no response to pork.

One month later, because this patient had suffered ischemic heart disease we performed skin instead of oral tests. Three commonly used $\mathrm{H}_{2}$-receptor antagonists were prepared: cimetidine (100 mg/mL), ranitidine $(25 \mathrm{mg} / \mathrm{mL})$, and famotidine $(10 \mathrm{mg} /$ $\mathrm{mL}$ ). The patient did not respond to any of the $\mathrm{H}_{2}$-receptor antagonists. Subsequently, intradermal skin tests using cimetidine, ranitidine, and famotidine at 1:10,000, 1:1,000, and 1:100 dilutions in $\mathrm{NaCl}$ were performed. If no response was observed, the concentration was increased in ten-fold steps. Cimetidine began to provoke a response at a 1:100, and ranitidine and famotidine at a 1:10 dilution (Table 1). No systemic response was observed.

Later, we identified acetaminophen to be safe to take orally.
Table 1. Results of intradermal skin tests for cimetidine, famotidine, and ranitidine

\begin{tabular}{lccccr}
\hline Drug & $1: 10,000$ & $1: 1,000$ & $1: 100$ & $1: 10$ & $1: 1^{*}$ \\
\hline Cimetidine & $0 \times 0 / 0 \times 0^{\dagger}$ & $0 \times 0 / 0 \times 0$ & $6 \times 6 / 28 \times 34$ & $7 \times 7 / 30 \times 35$ & $8 \times 8.5 / 40 \times 40$ \\
Famotidine & - & - & $0 \times 0 / 0 \times 0$ & $5 \times 8 / 22 \times 22$ & $6 \times 8 / 25 \times 35$ \\
Ranitidine & - & - & $0 \times 0 / 0 \times 0$ & $2 \times 3 / 10 \times 12$ & $6 \times 8.5 / 18 \times 20$ \\
Saline & - & - & - & - & $0 \times 0 / 0 \times 0$ \\
\hline
\end{tabular}

*Concentrations used were: cimetidine, $100 \mathrm{mg} / \mathrm{mL}$; famotidine, $10 \mathrm{mg} / \mathrm{mL}$; and ranitidine, $25 \mathrm{mg} / \mathrm{mL}$.

${ }^{\dagger}$ Data are expressed as increased wheal diameter $(\mathrm{mm} \times \mathrm{mm}) /$ flare diameter (mm×mm).

Chlorpheniramine was found to be safe after it was well-tolerated when accidentally injected in an emergency room. As a result, this case was diagnosed as cimetidine-induced anaphylaxis with possible cross-reactivity with famotidine and ranitidine.

\section{DISCUSSION}

The discovery of specific $\mathrm{H}_{2}$-receptor antagonists in the $1970 \mathrm{~s}$ revolutionized the management of gastric acid-related disorders. Cimetidine, the oldest and most used $\mathrm{H}_{2}$-receptor antagonist, inhibits many isozymes of the cytochrome $\mathrm{P} 450$ enzyme system. ${ }^{2}$ Thus, this agent has a higher risk of drug interactions than newer $\mathrm{H}_{2}$-receptor antagonists. Ranitidine, introduced in 1981, was designed by replacing the imidazole ring of cimetidine with a furan ring. Ranitidine has only $10 \%$ of the affinity to CYP450 of cimetidine. ${ }^{3}$ Famotidine, developed in 1985 , was structured by substituting the imidazole ring with a 2-guanidinothiazole ring. It does not bind to CYP450, and so has not been associated with significant interactions. ${ }^{4}$

Apart from the known interactions of cimetidine, $\mathrm{H}_{2}$-receptor antagonists are generally well-tolerated. Severe hypersensitivity reactions are rare. ${ }^{1,5-11}$ According to the Uppsala Monitoring Center database for May 1999, the incidence of anaphylaxis represented $0.2-0.7 \%$ of all the reported adverse reactions to both $\mathrm{H}_{2-}$ receptor antagonists and proton pump inhibitors. ${ }^{9}$

Direct challenge is considered the gold standard for diagnosis of drug allergies. However, performance of a direct challenge to a patient is often difficult, due to potential fatalities or unknown underlying diseases. In such cases, a skin or in vitro test can be helpful. In this report, we performed skin tests in the second case due to the risks arising from his cardiac conditions. It is sometimes problematic to distinguish true reactions from false positivity in intradermal tests. According to the literature, however, in normal controls skin irritation was not provoked at the most commonly used doses $(20 \mathrm{mg} / \mathrm{mL}$ for famotidine, $75 \mathrm{mg} / \mathrm{mL}$ for ranitidine, and $150 \mathrm{mg} / \mathrm{mL}$ for cimetidine). ${ }^{1}$ In this case, the minimum concentrations that provoked a response were: $1 \mathrm{mg} /$ $\mathrm{mL}, 2.5 \mathrm{mg} / \mathrm{mL}$ and $1 \mathrm{mg} / \mathrm{mL}$, respectively, indicating true positivity.

Interestingly, both cases showed cross-reactivity with other $\mathrm{H}_{2}$ - 
Table 2. Summary of published reports on the cross-reactivity of hypersensitive reactions by $\mathrm{H}_{2}$-receptor antagonists

\begin{tabular}{|c|c|c|c|c|}
\hline Case & Causative drug & Reaction & Cross-reactivity between & Diagnostic method \\
\hline Case 1 & Ranitidine & Anaphylaxis & Ranitidine and famotidine & Oral challenge \\
\hline Case 2 & Cimetidine & Anaphylaxis & Cimetidine, ranitidine and famotidine & Intradermal test \\
\hline Demirkan et al. ${ }^{9}(2006)$ & Ranitidine, famotidine & Angioedema, anaphylaxis & Famotidine and ranitidine & Clinical diagnosis \\
\hline Kim et al. ${ }^{1}(2010)$ & Famotidine & Anaphylaxis & $\begin{array}{l}\text { Nizatidine, ranitidine and famotidine, } \\
\text { but (-) cimetidine }\end{array}$ & Intradermal test \\
\hline Bossi et al. ${ }^{13}$ (1992) & Ranitidine, famotidine & $\begin{array}{l}\text { Maculopapular eruption, } \\
\text { pruritus }\end{array}$ & $\begin{array}{l}\text { Nizatidine, ranitidine and famotidine, } \\
\text { but (-) cimetidine, (-) roxatidine }\end{array}$ & $\begin{array}{l}\text { Skin prick test, } \\
\text { oral challenge }\end{array}$ \\
\hline Morisset et al. ${ }^{12}(2000)$ & Ranitidine, nizatidine & Maculopapular eruption & Ranitidine and nizatidine, but (-) famotidine & Oral challenge \\
\hline
\end{tabular}
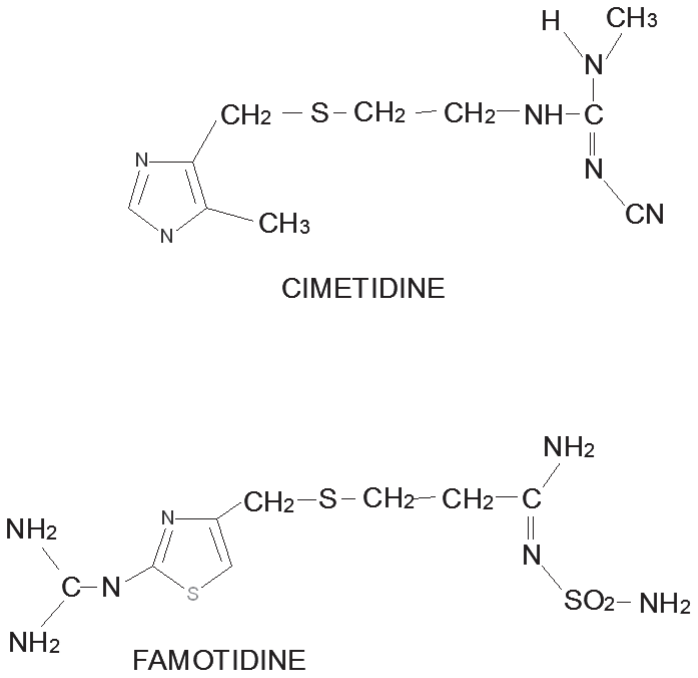
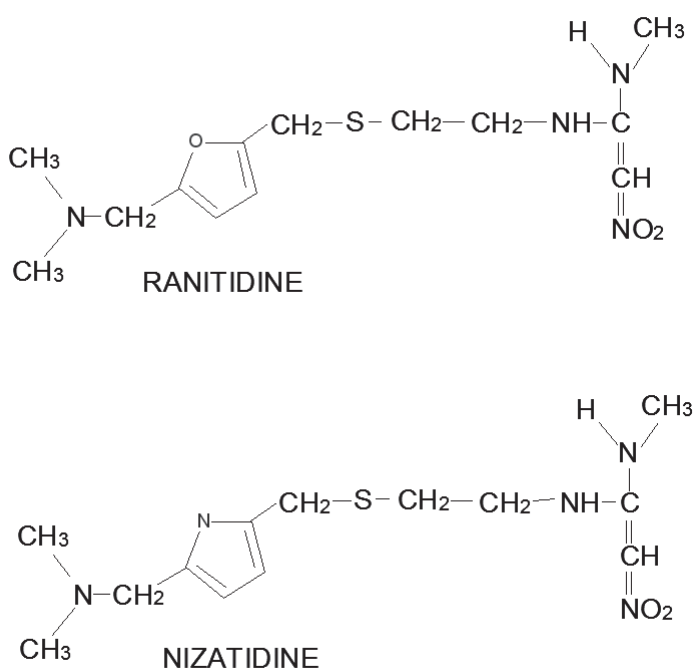

Figure. Chemical structures of $\mathrm{H}_{2}$-receptor antagonists.

receptor antagonists. So far, only a few reports of this phenomenon have been published. We have summarized the literature published to date (Table 2). All of the cross-reactions were between famotidine and ranitidine or nizatidine, but none with cimetidine. ${ }^{1,9,12,13}$ This may be due to the differences between cimetidine and other $\mathrm{H}_{2}$-receptor antagonists in terms of their side chain and ring structures. Ranitidine, nizatidine, and famotidine, but not cimetidine, share similar side chains on the ring structures (Figure). ${ }^{12,13}$ This may explain the rarity of cross-reactions of cimetidine with other $\mathrm{H}_{2}$-receptor antagonists. To our knowledge, this is the first report of possible cross-reactivity of cimetidine with another $\mathrm{H}_{2}$-receptor antagonist.

An IgE-dependent mechanism has been suggested for anaphylaxis induced by $\mathrm{H}_{2}$-receptor antagonists, and rantidine-specific IgE antibody has been isolated from one case. ${ }^{8}$

In summary, we report two cases of $\mathrm{H}_{2}$-receptor antagonist hypersensitivity reactions, showing possible cross-reactivity within the class. The first case was ranitidine hypersensitivity showing cross-reactivity with famotidine, as determined by oral challenge tests. The second case was of cimetidine-induced anaphylaxis, together with possible cross-reactivity to ranitidine and famoti- dine, as determined by skin tests.

\section{ACKNOWLEDGMENTS}

This study was supported by grants from the Korean Health 21 R\&D Projects, Ministry of Health \& Welfare and Family Affairs, Republic of Korea (A030001).

\section{REFERENCES}

1. Kim YI, Park CK, Park DJ, Wi JO, Han ER, Koh YI. A case of famotidine-induced anaphylaxis. J Investig Allergol Clin Immunol 2010; 20:166-9.

2. Levine M, Law EY, Bandiera SM, Chang TK, Bellward GD. In vivo cimetidine inhibits hepatic CYP2C6 and CYP2C11 but not CYP1A1 in adult male rats. J Pharmacol Exp Ther 1998;284:493-9.

3. Mills JG, Koch KM, Webster C, Sirgo MA, Fitzgerald K, Wood JR. The safety of ranitidine in over a decade of use. Aliment Pharmacol Ther 1997;11:129-37.

4. Howden CW, Tytgat GN. The tolerability and safety profile of famotidine. Clin Ther 1996;18:36-54; discussion 35.

5. Walker AI, Werfel S, Kick G, Przybilla B. Repeated anaphylactic re- 
sponses induced by oral challenge with ranitidine. Acta Derm Venereol 2010;90:189.

6. Thurot-Guillou C, Bourrain JL, Jacquier JP, Beani JC. Anaphylactic reaction to ranitidine and dexchlorpheniramine. Eur J Dermatol 2007;17:170-1.

7. Rethnam U, Yesupalan RS. Anaphylactic reaction associated with Ranitidine in a patient with acute pancreatitis: a case report. J Med Case Reports 2007;1:75.

8. Koh YI, Park HS, Choi IS. Ranitidine-induced anaphylaxis: detection of serum specific IgE antibody. Allergy 2006;61:269-70.

9. Demirkan K, Bozkurt B, Karakaya G, Kalyoncu AF. Anaphylactic reaction to drugs commonly used for gastrointestinal system diseas- es: 3 case reports and review of the literature. J Investig Allergol Clin Immunol 2006;16:203-9.

10. Mira-Perceval JL, Ortiz JL, Sarrió F, Miralles JC, Hernández J, Negro-Alvarez JM, López-Sánchez JD, García-Sellés FJ, Pagán JA. Nizatidine anaphylaxis. J Allergy Clin Immunol 1996;97:855-6.

11. Lazaro M, Compaired JA, De La Hoz B, Igea JM, Marcos C, Dávila I, Losada E. Anaphylactic reaction to ranitidine. Allergy 1993;48:385-7.

12. Morisset M, Moneret-Vautrin DA, Loppinet V, Grandidier S. Crossallergy to ranitidine and nizatidine. Allergy 2000;55:682-3.

13. Bossi A, Romeo G, Pezzoli A. Side-effects, structure, and $\mathrm{H}_{2}$-receptor antagonists. Lancet 1992;339:1366. 